Dear Author,

Please, note that changes made to the HTML content will be added to the article before publication, but are not reflected in this PDF.

Note also that this file should not be used for submitting corrections. 


\title{
Antibiotic and synthetic growth promoters in animal diets: Review of ${ }_{07}$ impact and analytical methods
}

\author{
Q6 Manuel Gonzalez Ronquillo ${ }^{\mathrm{a}, ~ *}$, Juan Carlos Angeles Hernadez ${ }^{\mathrm{b}}$ \\ a Departamento de Nutricion Animal, Facultad de Medicina Veterinaria y Zootecnia, Universidad Autonoma del Estado de México, Instituto Literario 100, \\ 50000 Toluca, Mexico \\ ${ }^{\mathrm{b}}$ Programa de Maestría y Doctorado en Ciencias de la Producción y de la Salud Animal, Facultad de Medicina Veterinaria y Zootecnia, Universidad Nacional \\ Autonoma de México, Circuito Exterior, Ciudad Universitaria, Delegacion Coyoacan 04510, Mexico
}

\section{A R T I C L E I N F O}

\section{Article history:}

Received 16 May 2015

Received in revised form

29 February 2016

Accepted 1 March 2016

Available online $\mathrm{xxx}$

\section{Keywords:}

Antibiotics

Feed

Sustainable animal diets

Analytical methods development

Synthetic growth promoters

Chemical compounds studied in this article: Ampicillin (PubChem CID: 6249)

Bacitracins (PubChem CID: 439542)

Clenbuterol (PubChem CID: 16048573)

Chloramphenicol (PubChem CID: 5959)

Monensin (PubChem CID: 441145)

Oxytretacycline (PubChem CID: 54675779)

Ractopamine (PubChem CID: 56052)

Salbutamol (PubChem CID: 2083)

Tretacycline (PubChem CID: 54675776)

Tylosin (PubChem CID: 5280440)

Zeranol (PubChem CID: 216284)

\begin{abstract}
A B S T R A C T
Food quality and safety have been a significant and pressing issue in recent years. In light of the FAO's definition of food security - the physical, social and economic access to sufficient and nutritious food food safety plays a fundamental role. Animal feed and feeding is pivotal to the livestock industry, but the use of veterinary antibiotics (VAs) and synthetic growth promoters (SGP) diminishes the sustainability of the diets and can cause an accumulation of residues in animals (meat, milk and eggs) and the environment (water and soil pollution). Wastewater systems are another major pathway through which antibiotics and hormones can enter the environment, with negative consequences. In order to protect the planet through more sustainable feeding, the reduction of antibiotics and synthetic growth promoters is a key aim, in particular with the goal of reducing antibiotic resistance and allergies. Analytical methods play a crucial role in food analysis, to determine the presence of antibiotics and other additives. Recent methods are based on liquid chromatography with ultraviolet, fluorescence, or mass spectrophotometry detection, which is recognized as an essential technique in food analysis, able to identify more than 300 compounds in feed samples. In general, a monitoring program put in place to educate the population on the hazards of residues in animal products is necessary, in conjunction with a continuous decrease in the use of antibiotics and synthetic growth promoters in animal diets.
\end{abstract}

(c) 2016 Published by Elsevier Ltd.

\section{Introduction}

Food quality and safety have been a significant and pressing topic in recent years. In light of the FAO's definition of food security - the physical, social and economic access to sufficient and nutritious food - food safety plays a fundamental role. The concern about food safety on the part of scientists, food experts and informed consumers can be defined as the probability of not falling ill as a consequence of consuming a certain food (Grunert, 2005).

\footnotetext{
* Corresponding author.

E-mail address: mrg@uaemex.mx (M. Gonzalez Ronquillo).
}

This concern naturally includes the potential risks from consuming foodstuffs of animal origin.

Animal feed plays a large role in the sustainability of animal production systems. It is estimated that about $70 \%$ of animalproduction costs are attributable to the cost of feed. The choice of diet on the farm affects the animal production chain, because feed management must take into account such factors as genetic animal potential, agro-ecological conditions, market demand, management practices and the social and economic environment.

The "Sustainable Animal Diets" (StAnD) concept was developed by the Food and Agriculture Organization of the United Nations (FAO) in consultation with a large international group of experts (Makkar \& Ankers, 2014) to resolve issues of sustainable animal 
feed. The StAnD concept is based on the three dimensions of sustainability: Planet, People, and Profit.

To understand the notion of StAnD, it is first necessary to transcribe the concept of sustainability into a conceptual model based on clearly identified objectives and elements. The Planet dimension considers 15 elements that are considered essential for a sustainable animal diet. For example: "production of StAnD and its feeding should not use antibiotics or synthetic growth promoters".

Antibiotic growth promoters (AGP) can be defined as any medicines that destroy or inhibit bacterial growth and are administered at a low subtherapeutic dosage (Hughes \& Heritage, 2004). The use of these components has risen with the intensification of livestock farming as a consequence of increased consumer demand and improvements in the efficiency of conversion of natural resources to food animal products.

A wide range of veterinary antibiotics (VA) - natural, synthetic or semi-synthetic compounds with antimicrobial activity that can be administered orally (Phillips et al., 2004) - are used for disease control, as feed additives, or as synthetic growth promoters (SGP) within various sectors such as livestock farming, aquaculture and agricultural activities (Aust et al., 2008; Gao et al., 2012; Zuccato, Castiglioni, Bagnati, Melis, \& Fanelli, 2010). Agricultural activities represent a large proportion of the usage of antibiotics in worldwide antibiotic consumption.

The growth-promoting effects of antibiotics were discovered in the 1940s when chickens were fed feed containing by-products of tetracycline fermentation. In this case, the chickens exhibited higher growth rates than chickens that were not fed feed containing by-products (Phillips et al., 2004). Since then, the use of growth promoters has been expanded to include a wide range of antibiotics that are applied to several species.

In pigs, the first evidence of the beneficial effects of AGP in productive animal performance was also observed in the 1940s, Q1 with the studies carried out by Cunha and Burnside (1949) and Stokstad, Jukes, Pierce, Page, and Franklin (1949), who found that the addition of dried mycelia from aerobic cultures of Streptomyces aureofaciens that contained chlortetracycline residues (previously called aureomycin) to the feed of pigs improved their growth (Castanon, 2007) (Fig. 1). The administration of antibiotics as growth promoters in the 1940 s and 1950s was part of an initial approach of supplementation in animal feed known as the "animal protein factor" (APF). APF was described as an unidentified substance necessary for balanced swine and poultry rations; initially it was claimed that APF consisted of Vitamin B12 although later it was found that APF also contained growth-promoting factors (antibiotics).
Since pharmaceutical antibiotics do not bioaccumulate significantly (Thiele-Bruhn, 2003), a high proportion of VAs are excreted via urine, feces (Ostermanna et al., 2013), milk (Arikan, Mulbry, \& Rice, 2009; Halling-Sorensen, Jensen, Tjornelund, \& Montforts, 2001) and eggs (Idowu et al., 2010) as the non-metabolized parent compounds, or accumulate to a high concentration in tissues (Kim Q2 et al., 2012; Kwon et al., 2011). This may pose a real threat to the consumer, either through exposure to the residues, the transfer of antibiotic resistance (Butaye, Devriese, \& Haesebrouck, 2003) or increased allergies resulting from antibiotic presence in foods. However, there are differing opinions regarding the level of risk that antibiotic residues pose to human health. Some researchers suggest that the actual danger is minimal and that banning antibiotics might prove more harmful to human and animal health. Furthermore, certain studies support the rational and prudent use of antibiotics in all contexts (Phillips et al., 2004).

It is not easy to establish and quantify the relationship between the use of AGP and possible negative effects on animal health, human health and the environment. However, in line with available information and the precautionary principle, AGP has been banned in some countries (Europe Union, Council Directive 96/22/EC). Barton (2000) notes that antibiotic resistance is already wellestablished in bacterial populations in animals, humans and the environment; Hao et al. (2014) show that the misuse and overuse of AGP may culminate in the development of drug-resistant pathogens, with severe consequences for the treatment of bacterial infections in patients.

Phillips et al. (2004) report that the low dosages of antibiotics used for growth promotion are a quantified hazard. To address the need for proper analysis of antibiotics usage, new techniques that combine chemical extraction, chromatographic separation and subsequent determination of antibiotic activity by microbial assays have been developed (Blasco, Torres, \& Pico, 2007; Cronly et al., 2010; De Alwis \& Heller, 2010; Sczesny, Nau, \& Hamscher, 2003; Stolker, Zuidema, \& Nielen, 2007).

Antibiotics are not the only substance added to animal feed by livestock farmers. Anabolic steroids (natural steroids, xenobiotics and synthetic steroids) and $\beta$-agonists have been largely used in intensive meat production to improve the integration of nutrient availability and animal performance in beef cattle (Vaconcelos et al., 2008), sheep (Mondragon et al. 2010) and swine (Shao et al., 2009), mainly through their endocrine systems; this produces meat which appeals to consumers in accordance with current human dietary guidelines.

Animal scientists have been interested in improving efficiency and product composition through the modification of the hormonal

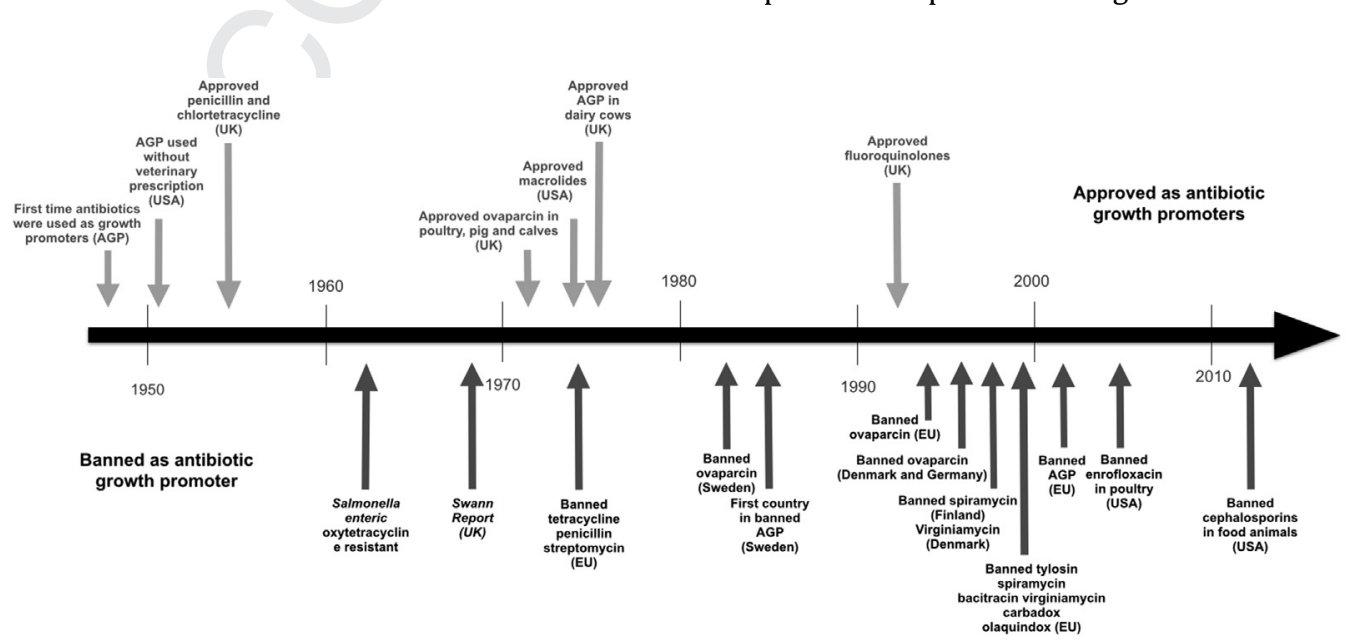

Fig. 1. Timeline of antibiotic growth promoters (AGP). 
state of animals. The history of hormonal treatments used as growth promoters includes attempts to identify useful hormones (natural sex hormones and related substances) and their correct dosage, as well as the development of better methods of administration, feed efficiency, carcass quality and the safety of their use for humans and animals (Fig. 2). Dinusson, Andrews, and Beeson (1948) carried out the first experiment to test the administration of an estrogen (diethylstilbestrol, DES) to ruminants with the aim of promoting growth; they found that DES improves weight gain (15\%) and feed conversion (10\%). Hale, Story, Culbertson, and Burroughs (1953) first administrated DES to ruminants in their feed.

Although natural and synthetic anabolic growth-promoting compounds have been widely utilized in animal production in recent decades to enhance their productive parameters, there is robust evidence that links the presence of growth promoter residues in animal feed components and animal diets with negative effects on human and animal health. The use of anabolic agents for growth promotion has become a concern due to the fact that animal excreta found in soil or water may disrupt endocrine activity in aquatic fauna or even terrestrial animals; Qu, Kolodziej, and Cwiertny (2012) demonstrated that the biotransformation of synthetic hormones in surface waters could have a profound impact on ecosystem health.

The above concerns about the use of VAs and SGPs in animal diets confirm the importance of effective analytical techniques to determine the presence of antibiotics or growth promoters in animal products and the level of bioaccumulation in tissues and in animal products used for human consumption, as well as in wastewater and manure. The current study examines the trend of research on the effect of antibiotic residues and synthetic growth promoters in animal diets and provides examples of new methodologies currently being used for the analysis of antibiotics and synthetic growth promoters in food for livestock production.

\section{Material and method}

\subsection{Database development}

Our informational search was focused on studies regarding feed supplementation with VAs or SGPs in animal feeds and their possible bioaccumulation in animal tissue or their excretion. A database was created from experiments where VAs and SGPs were specified. Publications were obtained from searches on various databases such as Scopus and Web of Science (WOS), which are known to extensively cover the fields of life sciences. Search strings were employed for a range of specific topics including the various types of antibiotics important in animal production, synthetic growth promoters, hormones and $\beta$-agonists. The search strings consisted of words associated with the particular topic, combined with the use of Boolean operators ("and", "or"). Data was compiled from publications between 2005 until April 2015. In the extensive search, the occurrence of all search terms within a string was checked for a title, abstract and keywords (i.e. the option "topic" in Web of Science" and "ALL" for all terms or by "TITLE-ABS-KEY" for title, abstract and keywords in Scopus). The outputs (of these substrings) were then combined using the operators "and" and "or" in order to retrieve records for references to the particular term occurring in animal feed and livestock.

According to Council Directive 96/23/EC, Annex 1 (European Commission, 1996) veterinary drugs and substances with anabolic effects used in animal feed are classified into two groups. Group A contains substances that have anabolic effects: stilbenes (diethylstilbestrol), steroids, androgens (trenbolone acetate), gestagens (melengestrol acetate), estrogens (17-b estradiol), resorcycilic acid lactones (zeranol), Beta-agonists (clenbuterol) and nitrofurans. Group B contains all the veterinary drugs in use. Taking into account the antibacterial substances, including sulfonamides and quinolones, in these groups and considering their impact on StAnD, the terms used in searching the database were as follows: Term 1: "antibiotic" or "antimicrobial" or "antibacterial" or "Growth promoter*" or "synthetic growth promoter"; Term 2: "steroidal hormone*" or "diethylstilbestrol" or "zeranol" or "trenbolone acetate" or "melengesterol acetate"; Term 3: "bst" or "rbst" or "growth hormone" or "rbGH" or "bovine somatotropine" or "recombinant bovine somatotropine"; Term 4: "Beta-adrenergic agonists" or "Beta-agonists" or "clenbuterol" or "zilpaterol" or "ractopamine" or "salbutamol" or "albuterol"; Term 5 "veterinary drug residue*”; Term 6 "new analytical methods" or "analysis"; Term 7 "residue* in

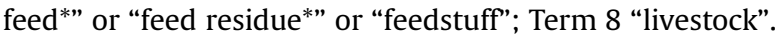

In Table 1, the outcomes of the "extensive" and "restrictive" searches are summarized, including the combination of terms and substrings. A reference was judged as relevant based on an association with animal feed, feedstuff and livestock.

\section{Results and discussion}

\subsection{Database description}

The results of the scientific database search, using the abovementioned terms, are listed in Table 1. There were differences both in quantity and type of information between WOS and Scopus. WOS of Thomson Reuters and Scopus of Elsevier Science are the most widespread databases on different scientific fields, used to search scientific literature. The results derived showed that the extensive and restricted searches of Term 1 and Term 7 provided

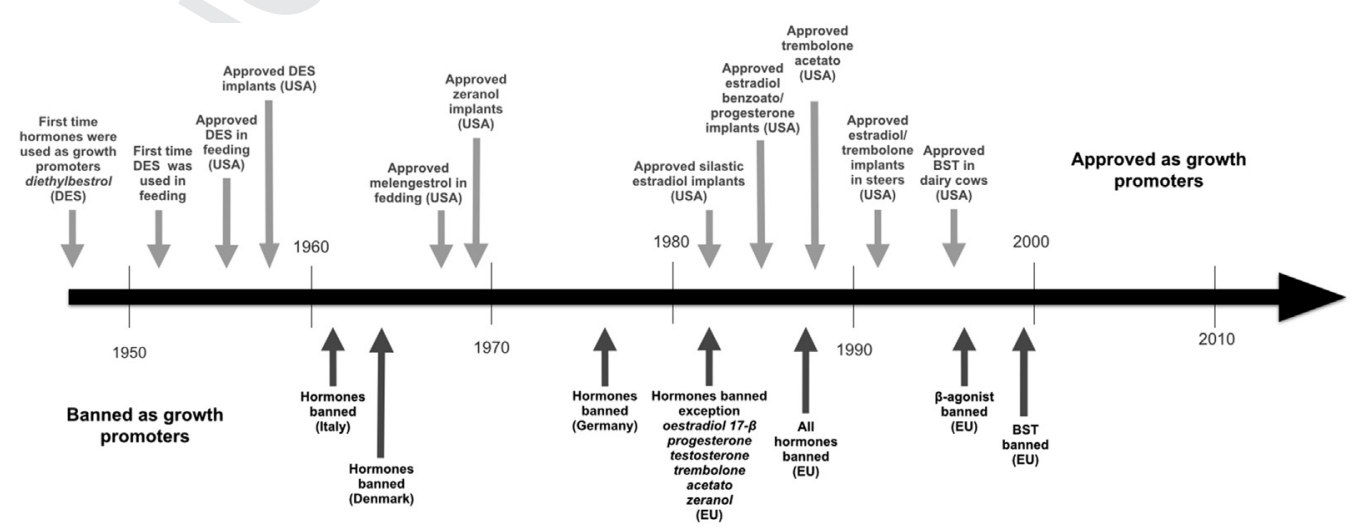

Fig. 2. Timeline of anabolic growth promoters. 
Table 1

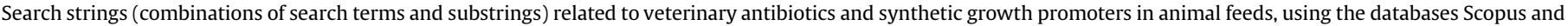
Web of Science (WOS).

\begin{tabular}{|c|c|c|c|c|c|c|}
\hline \multirow[b]{4}{*}{ Substring, topic } & \multicolumn{6}{|c|}{ Out puts } \\
\hline & \multicolumn{4}{|c|}{ Extensive search } & \multicolumn{2}{|c|}{ Restricted search } \\
\hline & \multirow{2}{*}{$\frac{\text { WOS }}{\text { All }}$} & \multirow{2}{*}{$\frac{\text { WOS }}{\text { Title/abst/kw }}$} & \multirow{2}{*}{$\frac{\text { Scopus }}{\text { All }}$} & \multirow{2}{*}{$\frac{\text { Scopus }}{\text { Title/abst/kw }}$} & \multirow{2}{*}{$\frac{\text { WOS }}{\text { Title }}$} & \multirow{2}{*}{$\frac{\text { Scopus }}{\text { Title }}$} \\
\hline & & & & & & \\
\hline \multicolumn{7}{|l|}{ Antibiotic } \\
\hline Term 1 and Term 7 & 1104 & 198 & 1648 & 470 & 67 & 155 \\
\hline Term 17 and 8 & 509 & 88 & 599 & 158 & 34 & 57 \\
\hline \multicolumn{7}{|l|}{ Steroidal hormones } \\
\hline Term 2 and 7 & 18 & 0 & 88 & 24 & 0 & 2 \\
\hline Term 27 and 8 & 11 & 0 & 40 & 12 & 0 & 2 \\
\hline \multicolumn{7}{|c|}{ Bovine somatrotropine } \\
\hline Term 3 and 7 & 257 & 17 & 204 & 27 & 7 & 10 \\
\hline Term 37 and 8 & 113 & 10 & 100 & 11 & 3 & 4 \\
\hline \multicolumn{7}{|c|}{ Beta-adrenergic agonists } \\
\hline Term 4 and 7 & 78 & 19 & 108 & 27 & 8 & 9 \\
\hline Term 47 and 8 & 46 & 14 & 49 & 9 & 6 & 4 \\
\hline \multicolumn{7}{|c|}{ Veterinary drugs residue } \\
\hline Term 5 and 7 & 300 & 21 & 114 & 21 & 10 & 7 \\
\hline Term 57 and 8 & 151 & 10 & 33 & 5 & 7 & 2 \\
\hline \multicolumn{7}{|l|}{ Analytical methods } \\
\hline Term 6 and 7 & 2441 & 25 & 9540 & 3261 & 2 & 390 \\
\hline Term 67 and 8 & 934 & 5 & 3301 & 841 & 0 & 99 \\
\hline Term 1678 & 192 & 1 & 480 & 130 & 0 & 22 \\
\hline Term 236 and 7 & 8 & 0 & 101 & 27 & 0 & 2 \\
\hline Terms 4567 and 8 & 83 & 1 & 66 & 35 & 0 & 13 \\
\hline
\end{tabular}

more results when using Scopus (with 67 results for WOS vs 155 for Scopus of restricted searches); the same tendency was shown with the combination of Terms 1,7 and 8 .

The search relating steroidal hormones with feed residues (Terms 2 and 7) had three times more results in Scopus than WOS; however, when the term livestock was added (Term 8) the results of the searches were similar. Vieira and Gomes (2009) previously compared the two databases and concluded that Scopus provides $20 \%$ more coverage than WOS. Other researchers have also preferred Scopus due to its quality of outcome, timesaving and ease of use (Boyle \& Sherman, 2006) (Table 1).

The WOS search presented better results when the terms "veterinary drug residue" and "residue in feed" (Terms 5 and 7) were added. When the term "livestock" was added to Terms 5 and 7, the search string provided more results in WOS than Scopus (Table 1). WOS is the oldest citation database; it has strong coverage of citation data and bibliographic data going back to 1900, and claims to have the most depth and quality range of records (Chadegani et al., 2013). The differences in search results when using both databases can be related with the size of each database. The WOS covers approximately 12,000 journals whereas Scopus has some 18,000 journals in its database.

The results of this extensive search are showed in the following sections: Veterinary antibiotics and synthetic growth promoters as pollutants in animal products and wastewater, Antibiotics in feed samples and New analytical methodologies for determination of antibacterial and synthetic growth promoters in food $\beta$-agonists and hormones in feed samples; Those provide an overview of the recent studies on AGP and anabolic growth promoters used in animal feed.

\subsection{Veterinary antibiotics and synthetic growth promoters as pollutants in animal products and wastewater}

\subsubsection{Effects of antibiotics in animal diets on animal and human health and environmental impact}

Antibiotics are used for three main purposes in animals: therapeutic use against infectious disease, prophylactic use for prevention of infectious animal diseases, and as feed additives to improve feed utilization and animal production (Fischer, Schilter, Tritscher, \& Stadler, 2011). Feed additives are defined as substances which improve both the feedstuffs in which they are incorporated and livestock production.

Van Boeckel et al. (2015) estimated that the consumption of antimicrobials in food animal production globally was 63,151 tons in 2010; they estimated that this consumption would increase by $67 \%$ by the year 2030 (105,569 tons). Antimicrobial consumption has a heterogenic geographic distribution, depending on the legislation in each continent and country, level of industrialization of animal production and characteristics of the market for food animal products. For example, in the US up to $80 \%$ of all antibiotics by volume used are in food production animals, where they are widely used as growth promoters; the US uses about 1.5 times as many antibiotics as Spain, one of the heaviest European users (Cully, 2014).

According to Van Boeckel et al. (2015) the five countries with the largest shares of global antimicrobial consumption in food animal production are: China (23\%), the United States (13\%), Brazil (13\%), India (3\%) and Germany (3\%). There is an association between intensive farming practices and the level of utilization of AGP; countries with intensive farming practices and dense food animal populations are generally associated with high consumption of AGP. These authors estimate antimicrobial consumption based on species-specific coefficients on antimicrobial consumption per population correction unit (PCU). In the OECD countries, antimicrobial consumption was lower in cattle (45 mg/PCU) than for chickens (148 mg/PCU) and pigs (172 mg/PCU).

The majority of the VAs that are administered to feed animals via feedstuffs are antimicrobials; AGPs are usually used in intensive systems administered via medicated feed. Worldwide, the aim of intensive livestock farming is to achieve high levels of food production at low cost per unit produced, but it is usually associated with an increase in the use of AGP. In the United States tetracyclines make up more than two thirds of antimicrobials administered to animals, whereas in Europe they account for only 37\% (Fig. 3); this 
route of administration leads to variability in dosage - as the animal can choose how much feed or water to consume - and thus promotes antibiotic resistance (FDA, 2015a).

The feedstuffs also can contain antibiotic residues through their contamination by, for instance, wastes in their environment originating from animals that consumed AGP in rangeland or crop areas, volatilization, or contaminated equipment used to prepare animal rations (mills, mixers, etc.). There is little in the scientific literature about the contamination of feedstuffs with AGP as a specific source of residues in animal products. McEvoy (2002) states that crosscontamination of feeding stuffs is a significant problem.

The use of antibiotics in food animal production offers proven benefits in animal health and production, as well as a reduction of foodborne pathogens (Mathew, Cissell, \& Liamthong, 2007). However, the over-use, misuse or lack of control in administration of antibiotics results in a high accumulation of antibiotics in the animal and its excretion to the environment. Harmful effects of AGP in feedstuffs on animals may occur if the compound has a low margin of safety in that species or if it adversely interacts with other medicines or microbial effects (McEvoy, 2002). Rice, McMurray, and Davidson (1983) reported toxicological effects of lincomycin in dairy feed, with the affected cows showing anorexia, diarrhea and ketosis.

The main implication of the addition of AGP to feedstuffs is the presence of potentially harmful residues in the meat and other edible products derived from animals. Olatoye and Ehinmowo (2010) determined that approximately $54 \%$ of the oxytetracycline administered could be detected in residues in cattle. According to FDA reports, tetracyclines show the highest level of drug use in animal feed (35\% of the total antimicrobial drugs approved for use in food-producing animals), followed by polymixins (FDA, 2012). McEvoy (2002) analyzed the presence of antimicrobials in feedstuffs and noted that the most frequently identified components were chlortetracycline (15.2\%), sulphonamides (6.9\%), penicillin (3.4\%) and ionophores (3.4\%).

A main concern for human health is the development of antibiotic resistance in bacteria that can cause disease in humans. While misuse of antibiotics in human medicine is a major cause of this problem, antibiotic resistance originating from the use of AGP in animals is a factor that can exacerbate this global human health issue (WHO \& FAO, 2015). Resistant bacteria evolve through the usage of antimicrobials and a correlation exists between the extent of usage and the prevalence of resistance under most circumstances (Jensen, Hammerum, Hasman, \& Aarestrup, 2002).

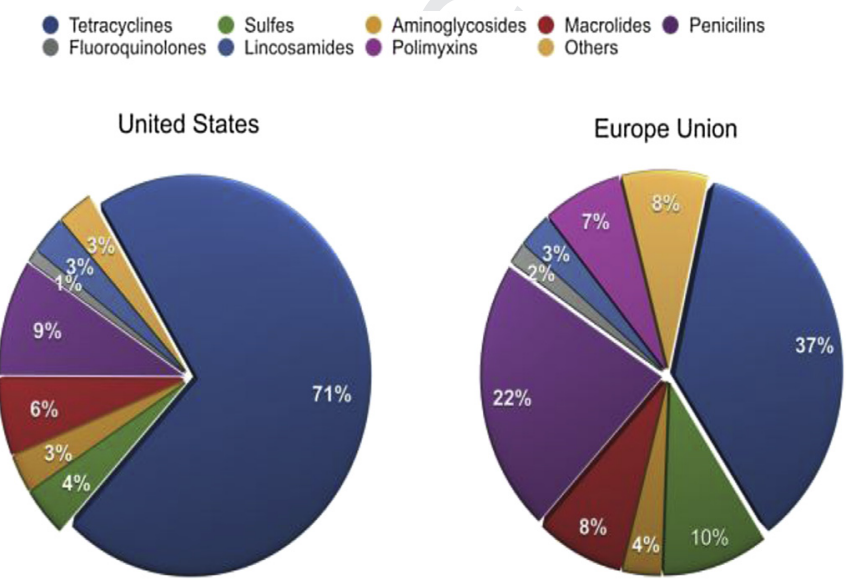

Fig. 3. Antimicrobials used in food producing animals in the United States and Europe Union.
The transfer of genes for antibiotic resistance and the selection of resistant bacteria can arise through several mechanisms (Mathew et al., 2007; Roe \& Pillai, 2003). There are two stages in the emergence of antibiotic-resistant bacteria: the first is genetic change, which can result from mutation (for example, resistance to fluoroquinolone) or because an existing antibiotic-resistant gene is transferred into the bacterium from another resistant bacterium (horizontal and lateral bacterial resistance transfers) (Martinez \& Baquero, 2000). Roe and Pillai (2003) have identified the integron gene sequence as the bacteria's primary method for acquisition of antimicrobial resistance genes. The second stage is the expansion by selection: once a gene or mutation for resistance is present and expressed, the cells containing it are able to survive and reproduce in the presence of the antibiotic and therefore increase in number at the expense of the vulnerable cells; resistant organisms are thus favored (JETACAR, 1999).

The potential of resistant bacteria contaminating milk and dairy products is a particular concern. Milk and dairy consumption vary according to geographic region, market and economic conditions and food traditions, among other factors. However, in the process of evaluating the safety of milk as a source of contamination, special attention must be placed on products for infants and children. Consumption of milk by infants and children is an important source of nutrients, and it is consumed in higher quantities compared to adults. For this reason, levels of exposure to any contaminants are correspondingly higher. Pereira et al. (2014) evaluated the effect of antimicrobial use on drug resistance in fecal E. Coli isolated from pre-weaned dairy calves and found that samples from enrofloxacine-treated calves had a higher $(P<0.0001)$ probability of being resistant to fluoroquinolones. This result is particularly disturbing, as these antibiotics are critical in human medicine for treatment against Salmonella, Campylobacter and Shigella bacteria (Collignon, Powers, Chiller, Aidara-Kane, \& Aarestrup, 2009). Other reports describe further instances of antibiotic and anthelmintic residues in dairy products (Berardi, Bogialli, Curini, Di Corcia, \& Laganá, 2006; Gomez-Perez, Romero-Gonzalez, Martinez, \& Garrido Frenich, 2013).

Antibiotics used to combat mastitis-causing pathogens are the most common antimicrobial agents used in the dairy industry (Fischer et al., 2011). LeBlanc, Osawa, \& Dubuc (2011) carried out an extensive review of antimicrobial resistance in adult dairy cows and concluded that the use of antibiotics in the dairy industry for the treatment and prevention of this condition does contribute to antimicrobial resistance, but this use provides more advantages than disadvantages. Other concerns about the presence of antimicrobial residues in milk and dairy products include the possibility of such residues causing allergic reactions.

In poultry, as well, there are concerns about the spread of antibiotic resistant bacteria. The selection pressure for resistant bacteria in poultry is high, and consequently their fecal flora contents have a relative high proportion of resistant bacteria. Van den Bogaard, London, Driessen, and Stobberingh (2001) analyzed antimicrobial resistance in feces of turkeys, broilers and hens producing eggs for human consumption and found strong evidence of the spread of antibiotic resistant Escherichia coli from animals to people. The resistant fecal $E$. coli from poultry can infect humans directly, via farmers and foods, for example when eggs are contaminated during laying. Idogu et al. (2010) also found that 3.6\% of eggs in supermarkets tested positive for antibiotics, mainly tetracyclines.

Endtz et al. (1991) noted that the first evidence of resistance to Campylobacter jejuni infection in humans in the Netherlands coincided with the introduction of enrofloxacin in poultry therapy in spring 1987. Several authors suggest that the use of antibiotics in veterinary practice is the primary cause of the drug resistance 
found in human strains of Yersinia enterocolitica (Kwaga \& Iversen, 1990).

Many antibiotics and hormones administered to animals cannot be completely absorbed or metabolized in the body and are directly excreted into the sewage system (Bartelt-Hunt, Snow, DamonPowell, \& Miesbachc, 2011; Bendz, Paxéus, Ginn, \& Loge, 2005; Kim et al., 2013). As a result, wastewater systems are a major pathway for the disposal and dispersal of antibiotics (Al-Rifai, Khabbaz, \& Schafer, 2011). Many antibiotics in wastewater are eliminated by sorption and transferred to sewage sludge during sewage treatment (Hörsing et al., 2011; Li, Du, Yu, Xu, \& You, 2013; Li, Shi, Gao, Liu, \& Cai, 2013), indicating that sludge can serve as an important reservoir for antibiotics. In addition, it has been recognized that the disposal of sludge, such as for agricultural application and landfill, can potentially release the antibiotics into the environment and may pose potential risks to animal and human health ecosystems (Sapkota et al., 2008; Wu, Spongberg, Witter, Fang, \& Czajkowski, 2010).

\subsubsection{Effects of anabolic growth promoters on animal and human} health and environmental impact

The continual increase in the global demand for feedstuffs encourages the development of novel strategies and technologies to enhance animal productivity, promoting the food supplementation that guarantees food security. Several biological and chemical substances are used to improve animal production performance. The recombinant Bovine Somatotropine (rBST) has been used to enhance milk production in the dairy industry; likewise, biological and chemical components with an anabolic effect, called growthpromoting agents, such as steroid hormones and $\beta$-agonist, have been used in the meat industry. The increase in milk production resulting from the administration of rBST is approximately $15 \%$ under optimal management conditions. The efficiency of growth promotion ranges between $0 \%$ and $20 \%$, depending on such factors as animal species, breed, gender, age, reproductive status, body condition score and feeding level (Meyer, 2001).

Anabolic steroids enhance body protein accretion and metabolize fat stores, resulting in increased lean growth rates (Smith, 2014). For this reason, anabolic steroids have been used in animal production systems for many years to increase growth rate $(+10-30 \%)$, feed efficiency $(+5-15 \%)$ and carcass leanness (+5-8\%) (Meyer, 2001; Stolker et al., 2007). Anabolic feed additives have been banned in the Europe Union; substances with hormonal and thyrostatic action were banned in 1988 (EU, 1988) and $\beta$ agonist was banned in 1996 (EU, 1996); however, in the United States two hormones are approved as feed additives: melengestrol acetate (MGA) for feedlot heifers and ractopamine for swine. Other anabolic growth promoters are usually implanted in the animal's ear so that the active substance is released slowly into the bloodstream.

The use of hormonal growth promoters in several countries outside the Europe Union is a primary concern, since the residual hormones found not only in meat, milk and other animal products, but also in soil and water originating from animal excreta, may have negative effects on endocrine activity in aquatic fauna and terrestrial animals (Lange et al. 2002). Various anabolic steroids have been detected in meat samples (Bussche et al., 2014; Vanhaecke, Vanden Bussche, Wille, Bekaert, \& De Brabander, 2011) and milk samples have been found to contain diethylstilbestrol (DES) (Secundo, Bacigalupo, Scalera, \& Quici, 2012), which is responsible for a higher incidence of vaginal and cervical adenocarcinoma as well as an increased risk of infertility in women (Schrager \& Potter, 2004).

Anabolic growth promoter residues can also be found in contaminated feed, leading to adverse effects in animal health and reproductive performance. Griel, Kradel, and Wickersham (1969) reported on abortions in cattle fed broiler litter containing estrogens. Shore, Shemesh, and Cohen (1988) noted that the consumption of chicken manure silage containing about $300 \mathrm{mg} / \mathrm{kg}$ of DM estrogens fed to non-pregnant heifers caused hyperestrogenism.

$\beta$-agonists are a class of substances that act on adrenergic receptor with anabolic effects in animals (Smith, 2014). Al-Doski, Hemmings, Daniel, Brameld, and Parr (2015) mentioned that $\beta$ agonists (cimaterol) administered to sheep increase glycolytic potential in muscles, which is associated with a capacity to increase the synthesis of serine and presumably other related metabolites required for growth. Nazli, Çolak, Aydin, and Hampikyan (2005) carried out the detection of anabolic residues in meat and meat products; they found levels of $\beta$-agonist and steroidal anabolic higher than acceptable limits and noted that meat and meat products with excessive levels of anabolic residues might be harmful for the consumer.

The safety in humans of growth-promoting products used appropriately in meat production has been confirmed by several international organizations (Food and Agriculture Organization, World Health Organization, US FDA) (Preston, 1999). However, it is important that current research focus on the development of techniques for detecting miniscule levels of drug residues and carry out long-term studies on the potential effects of the accumulation of drug residues in human tissues.

Endogenous hormones of animal origin have been released and deposited in environmental for thousands of years; however, recent years have seen a significant increase due to the increasing population and more intensive farming practices (Lange et al., 2002). The synthetic growth promoters used over the last five decades to improve animal production performance exhibit a high chemical stability and low deactivation via biotransformation, and may thus affect the ecological balance due to their prolonged persistence in the environment.

Estrogen, testosterone, 4-androstenedione, and androsterone have been detected in wastewater impoundments derived from pig farms (Bartelt-Hunt et al., 2011). The co-occurrence of VAs and steroid hormone contamination in groundwater and the correlation between pharmaceutical occurrence in lagoon wastewater and hydraulically downgradient groundwater indicates that groundwater underlying some livestock wastewater impoundments is susceptible to contamination by VAs and steroid hormones originating in wastewater lagoons (Qin, Zhao, Sawyer, \& Li, 2008). Effects of exogenous natural and synthetics hormones in different aquatic species have been reported, such as the reduction of testicular growth in rainbow trout (Jobling, Sumpter, Sheahan, Osborne, \& Matthiessen, 1996) and in testis and ovary size in zebrafish (Van den Belt, Wester, van der Ven, Verheyen, \& Witters, 2002).

\subsection{Antibiotics in feed samples}

VAs which are forbidden in animal foods and feeds are regulated in the European Union by Directive 96/23/EC (European Commission, 1996), which focuses on measures to monitor substances and residues in live animals and animal products. Analytical methodologies, including criteria for identification and confirmation for the monitoring of compliance, are described in the European Commission Decision 2002/657/CE (European Commission, 2002). In recent years, rapid methods with the advantage of easy performance, high sensitivity and high throughput are being proposed and used extensively.

The new analytical methods for determining levels of VAs in food and feed for livestock are shown in Table 3. Antibiotics should include only five classes - penicillins, tetracyclines, macrolides, 
Table 2

Maximum residue limits (MRLs) of antimicrobials and anabolic in foodstuffs of animal origin.

\begin{tabular}{|c|c|c|c|c|c|}
\hline Substance & Chemical group & Animal species & Matrix & MRLs $(\mu \mathrm{g} / \mathrm{kg})$ & Reference \\
\hline \multicolumn{6}{|l|}{ Antimicrobials } \\
\hline \multirow[t]{5}{*}{ Amoxicillin } & \multirow[t]{5}{*}{$\beta$-lactam } & \multirow[t]{5}{*}{ All food producing species } & Muscle & 50 & Commission Regulation \\
\hline & & & Fat & 50 & (EEC) No $37 / 2010$ of \\
\hline & & & Liver & 50 & December 2009 \\
\hline & & & Kidney & 50 & (Official Journal of the \\
\hline & & & Milk & 4 & $\begin{array}{l}\text { European Union, L15/1, } \\
20 / 1 / 2010 \text { ) }\end{array}$ \\
\hline \multirow[t]{5}{*}{ Ampicillin } & \multirow[t]{5}{*}{$\beta$-lactam } & \multirow[t]{5}{*}{ All food producing species } & Muscle & 50 & Commission Regulation \\
\hline & & & Fat & 50 & (EEC) No 37/2010 of \\
\hline & & & Liver & 50 & December 2009 \\
\hline & & & Kidney & 50 & (Official Journal of the \\
\hline & & & Milk & 4 & $\begin{array}{l}\text { European Union, L15/1, } \\
\text { 20/1/2010) }\end{array}$ \\
\hline \multirow[t]{3}{*}{ Penicillin V } & \multirow[t]{3}{*}{$\beta$-lactam } & \multirow[t]{3}{*}{ Porcine } & Muscle & 25 & Commission Regulation \\
\hline & & & Liver & 25 & (EEC) No $37 / 2010$ of \\
\hline & & & Kidney & 25 & $\begin{array}{l}\text { March } 1992 \text { (Official } \\
\text { Journal of the European } \\
\text { Union, L145, 20/6/ } \\
\text { 2000) }\end{array}$ \\
\hline \multirow[t]{5}{*}{ Bacitracin } & \multirow[t]{5}{*}{ Polypeptides } & Bovine & Milk & 100 & Commission Regulation \\
\hline & & Rabbit & Muscle & 150 & (EEC) No $37 / 2010$ of \\
\hline & & & Fat & 150 & December 2009 \\
\hline & & & Liver & 150 & (Official Journal of the \\
\hline & & & Kidney & 150 & $\begin{array}{l}\text { European Union, L15/1, } \\
\text { 20/1/2010) }\end{array}$ \\
\hline \multirow[t]{5}{*}{ Chlortetracycline } & \multirow[t]{5}{*}{ Tetracyclines } & All food producing species & Muscle & 100 & Commission Regulation \\
\hline & & & Liver & 300 & (EEC) No $37 / 2010$ of \\
\hline & & & Kidney & 600 & December 2009 \\
\hline & & & Milk & 100 & (Official Journal of the \\
\hline & & & Eggs & 200 & $\begin{array}{l}\text { European Union, L15/1, } \\
20 / 1 / 2010 \text { ) }\end{array}$ \\
\hline Tetracycline & Tetracyclines & All food producing species & Muscle & 100 & Commission Regulation \\
\hline & & & Liver & 300 & (EEC) No $37 / 2010$ of \\
\hline & & & Kidney & 600 & December 2009 \\
\hline & & & Milk & 100 & (Official Journal of the \\
\hline & & & Eggs & 200 & $\begin{array}{l}\text { European Union, L15/1, } \\
20 / 1 / 2010 \text { ) }\end{array}$ \\
\hline Oxitetracycline & Tetracyclines & All food producing species & Muscle & 100 & Commission Regulation \\
\hline & & & Liver & 300 & (EEC) No $37 / 2010$ of \\
\hline & & & Kidney & 600 & December 2009 \\
\hline & & & Milk & 100 & (Official Journal of the \\
\hline & & & Eggs & 200 & $\begin{array}{l}\text { European Union, L15/1, } \\
\text { 20/1/2010) }\end{array}$ \\
\hline Gentamicin & Aminoglycosides & Bovine Porcine & Muscle & 50 & Commission Regulation \\
\hline & & Bovine & Fat & 50 & (EEC) No $37 / 2010$ of \\
\hline & & & Liver & 200 & December 2009 \\
\hline & & & Kidney & 750 & (Official Journal of the \\
\hline & & & Milk & 100 & $\begin{array}{l}\text { European Union, L15/1, } \\
20 / 1 / 2010 \text { ) }\end{array}$ \\
\hline Neomycin & Aminoglycosides & All food producing species & Muscle & 500 & Commission Regulation \\
\hline & & & Fat & 500 & (EEC) No $37 / 2010$ of \\
\hline & & & Liver & 500 & December 2009 \\
\hline & & & Kidney & 5000 & (Official Journal of the \\
\hline & & & Milk & 1500 & European Union, L15/1, \\
\hline & & & Eggs & 500 & $20 / 1 / 2010)$ \\
\hline Spectinomycin & Aminoglycosides & Ovine & Muscle & 300 & Commission Regulation \\
\hline & & & Fat & 500 & (EEC) No $37 / 2010$ of \\
\hline & & & Liver & 2000 & December 2009 \\
\hline & & & Kidney & 5000 & (Official Journal of the \\
\hline & & & Milk & 200 & $\begin{array}{l}\text { European Union, L15/1, } \\
\text { 20/1/2010) }\end{array}$ \\
\hline & & All other food producing species & Muscle & 300 & Commission Regulation \\
\hline & & & Fat & 500 & (EEC) No $37 / 2010$ of \\
\hline & & & Liver & 1000 & December 2009 \\
\hline & & & Kidney & 5000 & (Official Journal of the \\
\hline & & & Milk & 200 & $\begin{array}{l}\text { European Union, L15/1, } \\
20 / 1 / 2010 \text { ) }\end{array}$ \\
\hline Streptomycin & Aminoglycosides & Bovine, porcine, ovine, poultry & Muscle & 600 & Joint FAO/WHO Expert \\
\hline & & & Fat & 600 & Committee on Food \\
\hline & & & Liver & 600 & Additives (JECFA). WHO \\
\hline & & & Kidney & 1000 & food addives series, \\
\hline & & & Milk & 200 & 1998. \\
\hline Erythromycin & Macrolides & All food producing species & Muscle & 200 & Commission Regulation \\
\hline & & & Fat & 200 & (EEC) No $37 / 2010$ of \\
\hline & & & & & (continued on next page) \\
\hline
\end{tabular}


Table 2 (continued)

\begin{tabular}{|c|c|c|c|c|c|}
\hline Substance & Chemical group & Animal species & Matrix & MRLs $(\mu \mathrm{g} / \mathrm{kg})$ & Reference \\
\hline \multirow{10}{*}{ Tylosin } & \multirow{10}{*}{ Macrolides } & \multirow{10}{*}{ All food producing species } & Liver & 200 & \multirow{10}{*}{$\begin{array}{l}\text { December } 2009 \\
\text { (Official Journal of the } \\
\text { European Union, L15/1, } \\
\text { 20/1/2010) } \\
\text { Commission Regulation } \\
\text { (EEC) No 37/2010 of } \\
\text { December 2009 } \\
\text { (Official Journal of the } \\
\text { European Union, L15/1, } \\
\text { 20/1/2010) }\end{array}$} \\
\hline & & & Kidney & 200 & \\
\hline & & & Milk & 40 & \\
\hline & & & Eggs & 150 & \\
\hline & & & Muscle & 100 & \\
\hline & & & Fat & 100 & \\
\hline & & & Liver & 100 & \\
\hline & & & Kidney & 100 & \\
\hline & & & Milk & 50 & \\
\hline & & & Eggs & 200 & \\
\hline \multirow[t]{12}{*}{ Tilmicosin } & \multirow{12}{*}{ Macrolides } & \multirow[t]{4}{*}{ Poultry } & Muscle & 150 & \multirow{12}{*}{$\begin{array}{l}\text { Joint FAO/WHO Expert } \\
\text { Committee on Food } \\
\text { Additives (JECFA). WHO } \\
\text { food addives series, } \\
2009 .\end{array}$} \\
\hline & & & Liver & 2400 & \\
\hline & & & Kidney & 600 & \\
\hline & & & Skin and Fat & 250 & \\
\hline & & \multirow[t]{4}{*}{ Bovine, ovine } & Muscle & 100 & \\
\hline & & & Liver & 1000 & \\
\hline & & & Kidney & 300 & \\
\hline & & & Fat & 100 & \\
\hline & & \multirow[t]{4}{*}{ Porcine } & Muscle & 100 & \\
\hline & & & Liver & 1500 & \\
\hline & & & Kidney & 1000 & \\
\hline & & & Fat & 100 & \\
\hline Sulfonamide & Sulfonamide & All food producing species & Muscle & 100 & Commission Regulation \\
\hline & & & Fat & 100 & (EEC) No $37 / 2010$ of \\
\hline & & & Liver & 100 & December 2009 \\
\hline & & & Kidney & 100 & (Official Journal of the \\
\hline & & Bovine, ovine, caprine & Milk & 100 & $\begin{array}{l}\text { European Union, L15/1, } \\
20 / 1 / 2010 \text { ) }\end{array}$ \\
\hline Lincomycin & Lincosamides & All food producing species & Muscle & 100 & Commission Regulation \\
\hline & & & Fat & 50 & (EEC) No $37 / 2010$ of \\
\hline & & & Liver & 500 & December 2009 \\
\hline & & & Kidney & 1500 & (Official Journal of the \\
\hline & & & Milk & 150 & European Union, L15/1, \\
\hline & & & Eggs & 50 & $20 / 1 / 2010)$ \\
\hline Pirlimycin & Lincosamides & Bovine & Muscle & 100 & Commission Regulation \\
\hline & & & Fat & 100 & (EEC) No $37 / 2010$ of \\
\hline & & & Liver & 1000 & December 2009 \\
\hline & & & Kidney & 400 & (Official Journal of the \\
\hline & & & Milk & 100 & $\begin{array}{l}\text { European Union, L15/1, } \\
\text { 20/1/2010) }\end{array}$ \\
\hline Enrofloxacin & Fluoroquinolones & Bovine, ovine, caprine & Muscle & 100 & Commission Regulation \\
\hline & & & Fat & 100 & (EEC) No $37 / 2010$ of \\
\hline & & & Liver & 300 & December 2009 \\
\hline & & & Kidney & 200 & (Official Journal of the \\
\hline & & & Milk & 100 & $\begin{array}{l}\text { European Union, L15/1, } \\
20 / 1 / 2010 \text { ) }\end{array}$ \\
\hline Danofloxacin & Fluoroquinolones & Bovine, ovine, caprine, poultry & Muscle & 200 & Commission Regulation \\
\hline & & & Fat & 100 & (EEC) No $37 / 2010$ of \\
\hline & & & Liver & 400 & December 2009 \\
\hline & & & Kidney & 400 & (Official Journal of the \\
\hline & & All other food producing species & Muscle & 100 & European Union, L15/1, \\
\hline & & & Fat & 50 & $20 / 1 / 2010)$ \\
\hline & & & Liver & 200 & \\
\hline & & & Kidney & 200 & \\
\hline & & Bovine, ovine, caprine & Milk & 30 & \\
\hline Florfenicol & Amphenicols & Bovine, ovine, caprine & Muscle & 200 & Commission Regulation \\
\hline & & & Liver & 3000 & (EEC) No $37 / 2010$ of \\
\hline & & & Kidney & 300 & December 2009 \\
\hline & & Porcine & Muscle & 300 & (Official Journal of the \\
\hline & & & Skin and Fat & 500 & European Union, L15/1, \\
\hline & & & Liver & 2000 & $20 / 1 / 2010)$ \\
\hline & & & Kidney & 500 & \\
\hline & & Poultry & Muscle & 100 & \\
\hline & & & Skin and Fat & 200 & \\
\hline & & & Liver & 2500 & \\
\hline & & & Kidney & 750 & \\
\hline Tiamulin & Pleuromutilins & Porcine & Muscle & 100 & Europe Medicine \\
\hline & & & Liver & 500 & Agency (EMA). \\
\hline & & Poultry & Muscle & 100 & Veterinary medicines \\
\hline & & & Liver & 1000 & Maximum residues \\
\hline & & & Skin and Fat & 100 & limits, 2008. \\
\hline & & & Eggs & 1000 & \\
\hline Anabolics & & & & & \\
\hline $17 \beta$-estradiol & Natural steroids & - & - & UN & $\begin{array}{l}\text { Joint FAO/WHO Expert } \\
\text { Committee on Food }\end{array}$ \\
\hline
\end{tabular}


Table 2 (continued)

\begin{tabular}{|c|c|c|c|c|c|}
\hline Substance & Chemical group & Animal species & Matrix & MRLs $(\mu \mathrm{g} / \mathrm{kg})$ & Reference \\
\hline Progesterone & Natural steroids & - & - & UN & $\begin{array}{l}\text { Additives (JECFA). WHO } \\
\text { food additives series, } \\
2000 . \\
\text { Joint FAO/WHO Expert } \\
\text { Committee on Food } \\
\text { Additives (JECFA). WHO } \\
\text { food additives series, } \\
2000 \text {. }\end{array}$ \\
\hline Zeranol & Xenobiotics & - & $\begin{array}{l}\text { Muscle } \\
\text { Liver }\end{array}$ & $\begin{array}{l}2 \\
10\end{array}$ & $\begin{array}{l}\text { Joint FAO/WHO Expert } \\
\text { Committee on Food } \\
\text { Additives (JECFA). WHO } \\
\text { food additives series, } \\
1988 \text {. }\end{array}$ \\
\hline Trembolone acetate & Xenobiotics & - & $\begin{array}{l}\text { Muscle } \\
\text { Liver }\end{array}$ & $\begin{array}{l}2 \\
10\end{array}$ & $\begin{array}{l}\text { Joint FAO/WHO Expert } \\
\text { Committee on Food } \\
\text { Additives (JECFA). WHO } \\
\text { food additives series, } \\
1988 \text {. }\end{array}$ \\
\hline Melengestrol acetate & Synthetic steroids & - & $\begin{array}{l}\text { Muscle } \\
\text { Liver } \\
\text { Kidney } \\
\text { Fat }\end{array}$ & $\begin{array}{l}1 \\
10 \\
2 \\
18\end{array}$ & $\begin{array}{l}\text { Joint FAO/WHO Expert } \\
\text { Committee on Food } \\
\text { Additives (JECFA). WHO } \\
\text { food additives series, } \\
2006 \text {. }\end{array}$ \\
\hline
\end{tabular}

amino glycosides and amphenicols (Gentili, Perret, \& Marchese, 2005), which comprise the most commonly detected VAs in food and are also normally used for preventing and treating diseases in animals. In addition, they are also used to increase feed efficiency and to promote growth in food-producing animals at subtherapeutic levels, with the use of other compounds such as hormones and $\beta$-agonists. As previously stated, the overuse of antibiotics in the livestock industry and their release into the environment poses both human health and ecological risks (Barcelo, 2007).

Most growth promoters have now been banned within the EU, with a decrease in the use of VAs in recent years (EMA, 2014). By 1999 only four compounds (monensin sodium, salinomycin sodium, avilamycin and flavophospholipol) remained in the group of feed additive growth promoters, with a consumption of 786 tons in the Europe Union that represented 6\% of the total consumption of antibiotics; later all use of antibiotics as growth promoters was banned in the EU (EU, 2007). In 2012, the European Union sold 8046 tons of veterinary drugs (EMA, 2014). In the United States (US), 70\% of antimicrobials were used in livestock farming in 2002, representing eight times the amount used in human medicine (Kummerer, 2003). In 2013 US livestock producers purchased 14,900 tons of antimicrobials (FDA, 2015a,b). Contrary to what one should expect with Sustainable Animal Diets, in the US, domestic sales and distribution of antimicrobials approved for use in foodproducing animals increased by 17\% from 2009 through 2013.

According to Wierup (2001) the motivation of producers and veterinarians toward a more prudent use of antimicrobials should be based on education. Sweden was the first country to ban the use of AGP in 1986, and it was the farmers themselves who requested the ban, in part because a 1984 report showed that consumer confidence in meat safety had fallen after it was revealed that farmers were using 30 tons per year of VAs in food animal production (Cogliani, Goossens, \& Greko, 2011). Although in the United States several AGPs are approved for use in food-producing animals, recently the FDA has also proposed restrictions and a judicious use of antimicrobial growth promoters in light of the current information and advice suggesting that the subtherapeutic use may increase the risk of antimicrobial resistance (FDA, 2012).

Several organizations, such as the European Commission (1999, 2015), US Food and Drug Administration (FDA, 2015b), and Codex Alimentarius (FAO, 2014) have established maximum residue limits
(MRLs) for VAs in foodstuffs from animal origin (Table 2). Table 3 presents an overview of the methodological advances in the analysis of antibacterial residues and synthetic growth promoters in food as a result of implementation of the Commission Decision 2002/657/EC (European Commission, 2002), aimed at increasing environmental sustainability.

\section{4. $\beta$-agonists and hormones in feed samples}

The use of $\beta$-agonists and substances with hormonal or thyreostatic action are banned in the European Union and other countries around the world. However, sometimes restricted drugs may be added to feed illegally in order to promote increased muscle development or increased water retention and thus obtain an economical benefit through an unsustainable diet. The result is a fraudulent weight increase of meat with lower fat content, and the increased levels of residues that may remain in the tissue (Bussche et al., 2014) pose a real threat to the consumer through either exposure to the residues or allergy risk. For example, the ingestion of clenbuterol may result in food poisoning and cause muscle tremors, tachycardia, palpitation and dizziness (Chan, 1999).

\subsection{New analytical methodologies for determination of antibacterial and synthetic growth promoters in food}

Animal feed is a very complex matrix. Not only does the composition differ for each species, but starting materials also differ for each production batch, resulting in unique characteristics for each feed. The first problem encountered is that many antibacterial residues derive from parent compounds and metabolites, because most of the antibacterials administered to food-producing animals are oxidized, reduced, hydrolyzed, or biotransformed into water-soluble conjugates. The second problem is that there is no set of maximum residue limits (MRL) or clear guidelines for levels of residues permitted in animal feed, even though the EU defines the MRLs for antimicrobials in foodstuffs of animal origin (Table 2). The third problem is cross-contamination, which occurs when trace amounts of drugs or chemicals are incorporated into feeds that should not contain them. Affected batches typically result when produced on the same equipment immediately after the production of a medicated feed that legally contains the drug in question. Use 
Table 3

Common classes of veterinary drug residues and analytical techniques from food and feed in livestock.

\begin{tabular}{|c|c|c|c|}
\hline Term & Analytical method & Compound & References \\
\hline Antibiotic & $\begin{array}{l}\text { LC-MS } \\
\text { GC-MS }\end{array}$ & $\begin{array}{l}\text { Tetracycline, } \\
\text { oxytetracycline, } \\
\text { chlortetracycline, } \\
\text { sulfamethazine, } \\
\text { sulfamethoxazole, and } \\
\text { sulfadimethoxine }\end{array}$ & $\begin{array}{l}\text { Ahmed et al. 2015; } \\
\text { Le Bizec, Pinel, Antinag, \& J. P, 2009; } \\
\text { Baer, De la Calle, \& Taylor, } 2010\end{array}$ \\
\hline Antibiotic & LC-MS & $\begin{array}{l}\text { Ampicillin, penicillin G, } \\
\text { tetracycline, } \\
\text { oxytetracycline, } \\
\text { chlortetracycline, } \\
\text { bacitracin A, } \\
\text { virginiamycin M1, } \\
\text { chloramphenicol, } \\
\text { erythromycin A, } \\
\text { clarithromycin, tylosin } \\
\text { A, monensin A and } \\
\text { streptomycin. }\end{array}$ & De Alwis \& Heller, 2010 \\
\hline Antibiotics & LC-MS/MS analysis. & $\begin{array}{l}50 \text { antibacterials of } \\
\text { various classes, } \\
\text { aminocoumarin, } \\
\text { amphenicols, beta- } \\
\text { lactams, lincosamide, } \\
\text { macrolides, } \\
\text { diaminopyrimidine, } \\
\text { quinolones, } \\
\text { sulfonamides, } \\
\text { streptogramin, } \\
\text { pleuromutilin, } \\
\text { polypeptide, } \\
\text { quinoxaline, and } \\
\text { tetracyclines, and also } \\
\text { some benzimidazoles }\end{array}$ & Robert et al., 2015 \\
\hline Steroidal hormones & $\begin{array}{l}\text { Grains/enzyme-linked } \\
\text { immunosorbent assay } \\
\text { (ELISA), LC-UV-EC }\end{array}$ & Zeranol & Hsieh et al., 2012 \\
\hline B agonist & $\begin{array}{l}\text { Radioligand-receptor } \\
\text { binding assay }\end{array}$ & $\begin{array}{l}\text { Clenbuterol, Cimaterol } \\
\text { (CIM), mabuterol } \\
\text { (MAB) mapenterol } \\
\text { (MAP), ractopamine } \\
\text { (RAC), salmeterol (SAL) } \\
\text { and Zilpaterol }\end{array}$ & Boyd, Heskamp, Bovee, Nielen, \& Elliott, 2009 \\
\hline B agonist and Antibiotics & $\begin{array}{l}\text { Ultra-high pressure } \\
\text { liquid chromatography } \\
\text { - tandem mass } \\
\text { spectrometry (UHPLC- } \\
\text { MS/MS) }\end{array}$ & $\begin{array}{l}\beta \text {-agonists, sedatives, } \\
\text { nitro-imidazoles and } \\
\text { aflatoxins }\end{array}$ & Wang, Wang, Zhang, \& Su, 2014 \\
\hline B agonist & $\begin{array}{l}\text { Gas chromatography - } \\
\text { mass spectrometry } \\
\text { (GC-MS) }\end{array}$ & $\beta$-agonists & $\begin{array}{l}\text { Corcia, Morra, Pazzi, \& Vincenti, 2009; Yang et al., 2013; } \\
\text { He, Su, Zeng, Liu, \& Huang, } 2007\end{array}$ \\
\hline B agonist & $\begin{array}{l}\text { capillary } \\
\text { electrophoresis }\end{array}$ & $\beta$-agonists & Li et al., 2013a \\
\hline B agonist & $\begin{array}{l}\text { electro- chemical } \\
\text { methods }\end{array}$ & Clenbuterol & $\begin{array}{l}\text { Bo et al., 2013; } \\
\text { Wang et al., } 2013\end{array}$ \\
\hline B agonist & $\begin{array}{l}\text { Label-free gold } \\
\text { nanoparticles (AuNPs) } \\
\text { in the presence of } \\
\text { melamine }\end{array}$ & $\begin{array}{l}\text { Clenbuterol, } \\
\text { ractopamine, } \\
\text { salbutamol }\end{array}$ & $\begin{array}{l}\text { Xu et al., 2014; Zhang et al., 2012; } \\
\text { Zhou, Li, Liu, Fu, \& Zhang, } 2013 .\end{array}$ \\
\hline Antibiotics & LC-MS/MS & 14 veterinary drugs & Cronly et al., 2010 \\
\hline$\beta$-agonists and antibiotics & LC-MS/MS & 20 veterinary drugs & Zhang et al., 2013 \\
\hline
\end{tabular}

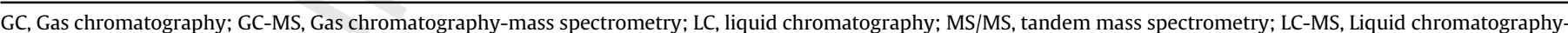
tandem mass spectrometry; LC-UV-EC, liquid chromatography incorporating ultraviolet (UV) absorbance and electrochemical dual-mode detection.

of these contaminated feeds may lead to the presence of residues in the animals consuming them (McEvoy, 2002).

This new technique for determining VAs and SGP in food incorporates new analytical methods (IAEA-FCRIS, 2015) that are able to analyze a large number of samples (Table 3 ), require less extracted solution, shorter clean-up cartridges time, and higher precision in improving recoveries and diminishing the risk of sample cross-contamination. The most popular immunoassays for detection of antibacterial residues are the immunochemical methods and the competitive enzyme-linked immunoassay (ELISA). Simple screening methods are highly advantageous for laboratories managing a large number of samples. ELISA tests provide semi-quantitative data and are particularly attractive.

In the field of food contaminant analysis, the most significant development of recent years has been the integration of ultra-high pressure liquid chromatography (UHPLC), coupled with tandem quadruple mass spectrometry (MS/MS), into analytical applications. Chromatographic procedures with different techniques have 
been used recently to determine antibiotics in food; liquid chromatography (LC) with ultraviolet (UV) fluorescence (FL) or mass spectrophotometry (MS) detection is the preferred option. LC and, more recently, ultra-performance LC (UPLC) are the techniques of choice for the determination of antimicrobials in the extracts. Gas chromatography (GC) combined with mass spectrophotometry (MS) has also been recently widely used for the determining the presence of different antibiotics and SGPs in animal food.

Most methods are designed to analyze several pharmaceuticals belonging to the same family of compounds, and methods covering several families of antimicrobials are still rare (Boscher, Guignard, Pellet, Hoffmann, \& Bohn, 2010; Cronly et al., 2010). Both UV and MS are widely applied as detection systems coupled with LC, and fluorimetry can also be advantageous for fluorescent compounds. UV and fluorimetric detectors are quite simple, robust and wellsuited for routine control of medicated feeds. In general, there is increasing interest in methods for the simultaneous analysis of various classes of veterinary drugs. In one run, such multi-residue analyses can deal with more than 300 compounds in feed samples (Gomez-Perez, Romero-Gonzalez, Martinez, \& Garrido Frenich, 2015) but only by using medium/high-resolution mass spectrometers (M-HRMS).

\section{Conclusions}

A review of recent research on the use of veterinary antibiotics, antibiotic growth promoters and synthetic growth promoters in food-producing animals reveals a growing awareness of the risks these supplements can pose - both for animal and human health and for the environment as a whole. The excessive use of antibiotics, particularly at a subtherapeutic dosage to promote growth, can fuel the development of antibiotic resistant bacteria, which put the health of both animals and humans at risk. Antibiotics also enter the environment through animal excreta and wastewater, as do anabolic growth enhancers, which can be particularly detrimental to aquatic animals. Residues of VAs and SGPs often remain in the animal products consumed by humans, which may cause various health issues, including allergies. Careful analysis of animal feed and animal products to detect the presence of these additives is a key step in monitoring their use. Recent methods include liquid chromatography with ultraviolet detection and mass spectrophotometry. Careful monitoring, education of the population on the hazards of residues in animal products, and the gradual reduction of the use of antibiotics and synthetic growth promoters in livestock are of utmost importance in ensuring the sustainability of animal production systems.

\section{Uncited references}

Awad et al., 2014, Commission Regulation March 1992, Council Directive march, Kim et al., 2011, Koh et al., 2007, Parr et al., 2009.

\section{Acknowledgment}

Angeles Hernandez thanks the National Council for Science and Technology (CONACyT, Mexico) for the scholarship at the Universidad Nacional Autonoma de Mexico; Dr. Gonzalez Ronquillo is grateful for his CONACyT fellowship "estancias sabaticas en el extranjero 2014". We thank Ilana Yablonovich and Pennelope Krumm for her critical review of this paper.

\section{References}

Ahmed, M. B. M., Rajapaksha, A. U., Lim, J. E., Vu, N. T., Kim, I. S., Kang, H. M., et al. (2015). Distribution and accumulative pattern of tetracyclines and sulfonamides in edible vegetables of cucumber, tomato, and lettuce. Journal of Agricultural and Food Chemistry, 63(2), 398-405.

Al-Doski, S., Hemmings, K., Daniel, Z., Brameld, J., \& Parr, T. (2015). Effects of growth promoters on expression of serine bosynthetic pathways genes in ovine liver and skeletal muscle. Advances in Animal Biocience, 6, 265.

Al-Rifai, J. H., Khabbaz, H., \& Schafer, A. I. (2011). Removal of pharmaceuticals and endocrine disrupting compounds in a water recycling process using reverse osmosis systems. Separation and Purification Technology, 77, 60-67.

Arikan, O. A., Mulbry, W., \& Rice, C. (2009). Management of antibiotic residues from agricultural sources: use of composting to reduce chlortetracycline residues in beef manure from treated animals. Journal of Hazardous Materials, 164, 483-489.

Aust, M. O., Godlinski, F., Travis, G. R., Hao, X., McAllister, T. A., Leinweber, P., et al. (2008). Distribution of sulfamethazine, chlortetracycline and tylosin in manure and soil of Canadian feedlots after subtherapeutic use in cattle. Environmental Pollution, 156, 1243-1251.

Awad, Y. M., Kim, S. C., Abd El-Azeem, S. A. M., Kim, K. H., Kim, K. R., Kim, K., et al. (2014). Veterinary antibiotics contamination in water, sediment, and soil near a swine manure composting facility. Environment Earth Sciences, 71, 1433-1440.

Baer, I., De la Calle, B., \& Taylor, P. (2010). 3 MCPD in food other than soy sauce or hydrolyzed vegetable protein (VHP). Analytical and Bioanalytical Chemistry, 396, $443-456$.

Barcelo, D. (2007). Pharmaceutical-residue analysis. TrAC Trends in Analytical Chemistry, 2, 454

Bartelt-Hunt, S., Snow, D. D., Damon-Powell, T., \& Miesbachc, D. (2011). Occurrence of steroid hormones and antibiotics in shallow groundwater impacted by livestock waste control facilities. Journal of Contaminant Hydrology, 123, 94-103.

Barton, M. D. (2000). Antibiotic use in animal feed and its impact on human health. Nutrition Research Reviews, 13(02), 279-299.

Bendz, D., Paxéus, N. A., Ginn, T. R., \& Loge, F. J. (2005). Occurrence and fate of pharmaceutically active compounds in the environment, a case study: Höje River in Sweden. Journal of Hazardous Materials, 122, 195-204.

Berardi, G., Bogialli, S., Curini, R., Di Corcia, A., \& Laganá, A. (2006). Evaluation of a method for assaying sulfonamide antimicrobial residues in cheese: hot-water extraction and liquid chromatography-tandem mass spectrometry. Journal of Agricultural and Food Chemistry, 54(13), 4537-4543.

Blasco, C., Torres, C. M., \& Pico, Y. (2007). Progress in analysis of residual antibacterials in food. Trends in Analytical Chemistry, 26, 895-913.

Boscher, A., Guignard, C., Pellet, T., Hoffmann, L., \& Bohn, T. (2010). Development of a multi-class method for the quantification of veterinary drug residues in feedingstuffs by liquid chromatography-tandem mass spectrometry. Journal of Chromatography, 1217, 6394.

Boyd, S., Heskamp, H. H., Bovee, T. F. H., Nielen, M. W. F., \& Elliott, C. T. (2009). Development, validation and implementation of a receptor based bioassay capable of detecting a broad range of $\beta$-agonist drugs in animal feeding stuffs. Analytica Chimica Acta, 637, 24-32.

Boyle, F., \& Sherman, D. (2006). Scopus: the product and its development. The Serials Librarian, 49(3), 147-153.

Bo, B., Zhu, X. J., Miao, P., Pei, D., Jiang, B., Lou, Y., et al. (2013). An electrochemical biosensor for clenbuterol detection and pharmacokinetics investigation. Talanta, 113, 36-40.

Bussche, J. V., Decloedt, A., Meulebroek, L. V., De Clercq, N., Lock, S., Stahl-Zeng, J., et al. (2014). A novel approach to the quantitative detection of anabolic steroids in bovine muscle tissue by means of a hybrid quadrupole time-of-flight-mass spectrometry instrument. Journal of Chromatography A, 1360, 229-239.

Butaye, P., Devriese, L. A., \& Haesebrouck, F. (2003). Antimicrobial growth promoters used in animal feed: effects of less well known antibiotics on gram-positive bacteria. Clinical Microbiology Reviews, 16, 175-188.

Castanon, J. I. R. (2007). History of the use of antibiotic as growth promoters in European poultry feeds. Poultry Science, 86(11), 2466-2471.

Chadegani, A., Salehi, A., Yunus, H., Farhadi, M. M., Fooladi, H., Farhadi, M., et al. (2013). A comparison between two main academic literature collections: web of science and scopus databases. Asian Social Science, 9(5), 18-26.

Chan, J. T. Y. K. (1999). Health hazards due to clenbuterol residues in food. Journal of Toxicology Clinical Toxicology, 37, 517-519.

Cogliani, C., Goossens, H., \& Greko, C. (2011). Restricting antimicrobial use in food animals: lessons from Europe. Microbe, 6(6), 274

Collignon, P., Powers, J. H., Chiller, T. M., Aidara-Kane, A., \& Aarestrup, F. M. (2009). World Health Organization ranking of antimicrobials according to their importance in human medicine: a critical step for developing risk management strategies for the use of antimicrobials in food production animals. Clinical Infectious Diseases, 49, 132-141.

Commission Regulation (EEC) No 37/2010 of December 2009 on pharmacologically active substances and their classification regarding maximum residue limits in foodstuffs of animal origin. Official Journal of the European Union, L15/1, 20/1/ 2010.

Commission Regulation (EEC) No 37/2010 of March 1992 on pharmacologically active substances and their classification regarding maximum residue limits in foodstuffs of animal origin. Official Journal of the European Union, L145, 20/6/ 2000.

Corcia, D. D., Morra, V., Pazzi, M., \& Vincenti, M. (2009). Simultaneous determination of b2-agonists in human urine by fast-gas chromatography/mass spectrometry: method validation and clinical application. Biomedical Chromatography, 24, 358-366.

Council Directive 88/146/EEC of 7 March 1988 prohibiting the use in livestock 
farming of certain substances having a hormonal action. Official Journal of the European Union, L Series, No. 70, pp. 16-18.

Council Directive 96/22/EC of 29 April 1996 concerning the prohibition on the use in stockfarming of certain substances having a hormonal or thyrostatic action and of beta-agonists, and repealing Directives 81/609/EEC, 88/146/ECC and 88/ 299/EEC. Official Journal of the European Union, L Series, No. 125, pp. 5-9.

Cronly, M., Behan, P., Foley, B., Malone, E., Earley, S., Gallagher, M., et al. (2010). Development and validation of a rapid multi-class method for the confirmation of fourteen prohibited medicinal additives in pig and poultry compound feed by liquid chromatography-tandem mass spectrometry. Journal of Pharmaceutical and Biomedical Analysis, 153, 929-938.

Cully, M. (2014). The politics of antibiotics. Nature, 509, 16-17.

Cunha, T. J., \& Burnside, J. E. (1949). Effect of vitamin B12, animal protein factor and soil for pig growth. Archives of Biochemistry, 23(2), 324.

De Alwis, H., \& Heller, D. N. (2010). Multiclass, multiresidue method for the detection of antibiotic residues in distillers grains by liquid chromatography and ion trap tandem mass spectrometry. Journal of Chromatography A, 1217, 3076-3084.

Dinusson, W. E., Andrews, F. N., \& Beeson, W. M. (1948). The effects of stilbestrol, testosterone and thyroid alterations on growth and fattening of beef heifers. Journal of Animal Science, 7, 523-524.

EMA (European Medicines Agency). (2014). European medicines agency, European surveillance of veterinary antimicrobial consumption, 'sales of veterinary antimicrobial agents in 26 EU/EEA countries in 2012'. (EMA/333921/2014).

Endtz, H. P., Ruijs, G. J., van Klingeren, B., Jansen, H. W., Van der Reyden, T., \& Mouton, R. P. (1991). Quinolone resistance in campylobacterisolated from man and poultry following the introduction of fluoroquinolones in veterinary medicine. Journal of Antimicrobial Chemotheraphy, 27, 199-208.

European Commission. (1996). Council directive 96/23/EC of 29 April 1996 on measures to monitor certain substances and residues thereof in live animals and animal products and repealing directives 85/358/EEC and 86/469/EEC and decision 89/187/EEC and 91/664/EEC. Official Journal of the European Union, L125, 10 (23 May 1996).

European Commission. (1999). European union, commission regulation 508/1999/ EC amending annexes I to IV to council regulation (EEC) No 2377/90 laying down community procedure for the establishment of maximum residue limits of veterinary medicinal products in foodstuffs of animal origin. Official Journal of the European Union, L224, 16.

European Commission. (2002). European union, commission decision 2002/657/EC implementing council directive $96 / 23 /$ EC concerning the performance of analytical methods and interpretation of results. Official Journal of the European Union, L239(66). http://europe.eu.int.

European Commission. (2015). Report from the commission to the European parliament and the council on the functioning of regulation (EC) No 470/2009 of the European parliament and of the council of 6 May 2009 laying down community procedures for the establishment of residue limits of pharmacologically active substances in foodstuffs of animal origin, repealing council regulation (EEC) No 2377/90 and amending directive 2001/82/EC of the European parliament and of the council and regulation (EC) No 726/2004 of the European parliament and of the council.

European Medicine Agency (EMA). (2008). Veterinary medicines-maximum residue limits (MRL). Summary Reports and EPMARs-Tiamulin (3) http://www.ema. europa.eu/pdfs/vet/mrls/074700en.pdf.

European Union. (2007). Council and parliament prohibit antibiotics as growth promoters: Commissioner Byrne welcomes adoption of regulation on feed additives. Brussels: Press release rapid, 22 July 2003.

FAO. (2014). Codex Alimentarius: maximum residue limits (MRLs) and risk management recommendations (RMRs) for residues of veterinary drugs in foods. In CAC/MRL 2-2014. 37th session of the codex alimentarius commission (july 2014).

FDA (U.S. Food and Drug Administration). (2012). Summary report of antimicrobial sold or distributed for used in food-producing animals. USA.

FDA (U.S. Food of Drug Administration). (2015a). Summary report on antimicrobials sold or distributed for use in food-producing animals. Silver Spring, MD: Center for Veterinary Medicine, U.S. Food and Drug Administration.

FDA (US Food and Drug Administration). (2015b). Us food and drug administration CFR - Code of federal regulations title 21.

Fisher, W. J., Schilter, B., Tritscher, A. M., \& Stadler, R. H. (2011). Environmental contaminants. In J. W. Fuquay, P. F. Fox, \& P. L. H. McSweeney (Eds.), Enclicopedia of dairy science (2nd ed.). U.K: Elsevier.

Gao, L., Shi, Y., Li, W., Niu, H., Liu, J., \& Cai, Y. (2012). Occurrence of antibiotics in eight sewage treatment plants in Beijing, China. Chemosphere, 86, 665-671.

Gentili, A., Perret, D., \& Marchese, S. (2005). Liquid chromatography-tandem mass spectrometry for performing confirmatory analysis of veterinary drugs in animal-food products. TrAC Trends in Analytical Chemistry, 24, 704.

Gomez-Perez, M. L., Romero-Gonzalez, R., Martinez, J. L., \& Garrido Frenich, V. A. (2013). Analysis of veterinary drug residues in cheese by ultra-highperformance LC coupled to triple quadrupole MS/MSJ. Journal of Separation Science, 36, 1223-1230.

Gomez-Perez, M. L., Romero-Gonzalez, R., Martinez, J. L., \& Garrido Frenich, V. A. (2015). Analysis of veterinary drug and pesticide residues in animal feed by high-resolution mass spectrometry: comparison between time-of-flight and Orbitrap. Food Additives \& Contaminants: Part A.

Griel, L. C., Jr., Kradel, D. C., \& Wickersham, E. W. (1969). Abortion in cattle associated with the feeding of poultry litter. The Cornell Veterinarian, 59(2), $226-235$.
Grunert, K. G. (2005). Food quality and safety: consumer perception and demand. European Review of Agricultural Economics, 32(3), 369-391.

Hale, W. H., Story, C. D., Culbertson, C. C., \& Burroughs, W. (1953). The value of low levels of stilbestrol in the rations of fattening lambs. Journal of Animal Science $12,918-918$.

Halling-Sorensen, B., Jensen, J., Tjornelund, J., \& Montforts, M. H. M. M. (2001). Worstcase estimations of predicted environmental soil concentrations (PEC) of selected veterinary antibiotics and residues used in Danish agriculture. In K. Kummerer (Ed.), Pharmaceuticals in the environment (pp. 143-157). Berlin: Springer Verlag.

Hao, H., Cheng, G., Iqbal, Z., Ai, X., Hussain, H. I., Huang, L., et al. (2014). Benefits and risks of antimicrobial use in food-producing animals. Frontiers in Microbiology, 5.

He, L., Su, Y., Zeng, Z., Liu, Y., \& Huang, X. (2007). Determination of ractopamine and clenbuterol in feeds by gas chromatography-mass spectrometry. Animal Feed Science and Technology, 132(3-4), 316-323.

Hörsing, M., Ledin, A., Grabic, R., Fick, J., Tysklind, M., Jansen, J. L. C., et al. (2011) Determination of sorption of seventy-five pharmaceuticals in sewage sludge. Water Research, 45, 4470-4482.

Hsieh, H. Y., Shyu, C. L., Liao, C. W., Lee, R. J., Lee, M. R., Vickroy, T. W., et al. (2012). Liquid chromatography incorporating ultraviolet and electrochemical analyses for dual detection of zeranol and zearalenone metabolites in mouldy grains. Journal of the Science of Food and Agriculture, 92(6), 1230-1237.

Hughes, P., \& Heritage, J. (2004). Antibiotic growth-promoters in food animals. In assessing quality and safety of animal feeds (pp. 129-151). Rome, Italy: FAO.

IAEA-FCRIS. (2015). Veterinary drugs residue methods, food contaminant and residues information system. http://nucleus.iaea.org/fcris/VetSubMethodList.aspx.

Idowu, F., Junaid, K., Paul, A., Gabriel, O., Paul, A., Sati, N., et al. (2010). Antimicrobial screening of commercial eggs and determination of tetracycline residue using two microbiological methods. International Journal of Poultry Science, 9(10), 959-962.

Jensen, L. B., Hammerum, A. M., Hasman, H., \& Aarestrup, F. M. (2002). Effects of the termination of antibiotic growth promoters use on presence of resistance genes in bacterial isolates from production animals. Beyond Antimicrobial Growth Promoters in Food Animal Production, 32.

Jobling, S., Sumpter, J. P., Sheahan, D., Osborne, J. A., \& Matthiessen, P. (1996). Inhibition of testicular growth in rainbow trout (Oncorhynchus mykiss) exposed to estrogenic alkylphenolic chemicals. Environmental Toxicology and Chemistry, 15(2), 194-202.

Joint FAO/WHO Expert Committee on Food Additives (JECFA). (1988). Evaluation of certain veterinary drug residues in food. WHO Technical Report Series, 763 $16-33$.

Joint FAO/WHO Expert Committee on Food Additives (JECFA). (1998). Toxicologica evaluation of certain veterinary drug residues in food: Dihydroestreptomycin and streptomycin. WHO food addives series.

Joint FAO/WHO Expert Committee on Food Additives (JECFA). (2000). Toxicological evaluation of certain veterinary drug residues in food: Estradiol-17 $\beta$, progesterone and testosterone (p. 43). WHO Food Additives Series.

Joint FAO/WHO Expert Committee on Food Additives (JECFA). (2006). Evaluation of certain veterinary drug residues in food. Melengestrol acetate (p. 939). WHO Technical Report Series.

Joint FAO/WHO Expert Committee on Food Additives (JECFA). (2009). Toxicological evaluation of certain veterinary drug residues in food: Tilmicosin. WHO food addives series.

Joint expert advisory committee on antibiotic resistance JETACAR. (1999). The use of antibiotics in food-producing animals: antibiotic-resistant bacteria in animals and humans. Commonwealth of Australia, 17-24.

Kim, K. R., Owens, G., Kwon, S. I., So, K. H., Lee, D. B., \& Ok, Y. S. (2011). Occurrence and environmental fate of veterinary antibiotics in the terrestrial environment. Water Air \& Soil Pollution, 214, 163-174.

Koh, Y. K., Chiu, T. Y., Boobis, A., Cartmell, E., Lester, J. N., \& Scrimshaw, M. D. (2007) Determination of steroid estrogens in wastewater by high performance liquid chromatography-tandem mass spectrometry. Journal of Chromatography $A$ 1173(1-2), 81-87.

Kummerer, K. (2003). Significance of antibiotics in the environment. Journal of Antimicrobial Chemotheraphy, 52, 5-7.

Kwaga, J., \& Iversen, J. O. (1990). In vitro antimicrobial susceptibilities of Yersinia enterocolitica and related species isolated from slaughtered pigs and pork products. Antimicrobial Agents and Chemotherapy, 34(12), 2423-2425.

Lange, I. G., Daxenberger, A., Schiffer, B., Witters, H., Ibarreta, D., \& Meyer, H. H. (2002). Sex hormones originating from different livestock production systems fate and potential disrupting activity in the environment. Analytica Chimica Acta, 473(1), 27-37.

Le Bizec, B., Pinel, G., \& Antinag, J. P. (2009). Options of veterinary drug analysis using mass spectrometry. Journal of Cromatography A, 1218, 1021-1036.

LeBlanc, J.,S., Osawa, T., \& Dubuc, J. (2001). Reproductive tract defense and disease in postpartum dairy cows. Theriogenology, 76(9), 1610-1618.

Li, L. B., Du, H. W., Yu, H., Xu, L., \& You, T. Y. (2013). Application of ionic liquid as additive in determination of three-agonists by capillary electrophoresis with amperometric detection. Electrophoresis, 34, 277-283.

Li, W., Shi, Y., Gao, L., Liu, J., \& Cai, Y. (2013). Occurrence, distribution and potential affecting factors of antibiotics in sewage sludge of wastewater treatment plant in China. Science of the Total Environment, 445-446, 306-313.

Makkar, H. P. S., \& Ankers, P. (2014). Towards sustainable animal diets: a surveybased study. Animal Feed Science and Technology, 309-322. 
Martinez, J. L., \& Baquero, F. (2000). Mutation frequencies and antibiotic resistance. Antimicrobial Agents and Chemotheraphy, 44, 1771-1777.

Mathew, A. G., Cissell, R., \& Liamthong, S. (2007). Antibiotic resistance in bacteria associated with food animals: a United States perspective of livestock production. Foodborne Pathogens and Disease, 4(2), 115-133.

McEvoy, J. D. G. (2002). Contamination of animal feedingstuffs as a cause of residues in food: a review of regulatory aspects, incidence and control. Analytica Chimica Acta, 473, 3-26.

Meyer, H. H. (2001). Biochemistry and physiology of anabolic hormones used for improvement of meat production. Apmis, 109(S103), S336-S344.

Mondragon, J., Dominguez Vara, I. A., Pinos Rodriguez, J. M., Gonzalez, M., Borquez, J. L., Dominguez, A., et al. (2010). Effects of feed supplementation of zilpaterol hydrochloride on growth performance and carcass traits of finishing lambs. Acta Agriculturae Scandinavica, Section A - Animal Science, 60(1), 47-52.

Nazli, B., Çolak, H., Aydin, A., \& Hampikyan, H. (2005). The presence of some anabolic residues in meat and meat products sold in Istanbul. Turkish Journal of Veterinary and Animal Sciences, 29(3), 691-699.

Olatoye, I. O., \& Ehinmowo, A. A. (2010). Oxytetracycline residues in edible tissues of cattle slaughtered in Akure, Nigeria. Nigerian Veterinary Journal, 31(2), 93-102.

Ostermanna, A., Siemensa, J. Welpa, G., Xueb, Q. Linb, X. Liuc, X., et al. (2013) Leaching of veterinary antibiotics in calcareous Chinese croplands. Chemosphere, 91(7), 928-934.

Parr, M. K., Offermann, G., \& Schanzer, W. (2009). Analytical methods for the detection on clenbuterol. Bioanalysis, 1, 437-450.

Pereira, R. V., Siler, J. D., Ng, J. C., Davis, M. A., Grohn, Y. T., \& Warnick, L. D. (2014) Effect of on-farm use of antimicrobial drugs on resistance in fecal Escherichia coli of preweaned dairy calves. Journal of Dairy Science, 97(12), 7644-7654.

Phillips, I., Casewell, M., Cox, T., De Groot, B., Friis, C., Jones, R., et al. (2004). Does the use of antibiotics in food animals pose a risk to human health? A critical review of published data. Journal of Antimicrobial Chemotherapy, 53(1), 28-52.

Preston, R. L. (1999). Hormone containing growth promoting implants in farmed livestock. Advanced Drug Delivery Reviews, 38(2), 123-138.

Qin, F., Zhao, Y. Y., Sawyer, M. B., \& Li, X. F. (2008). Column-switching reversed phase-hydrophilic interaction liquid chromatography/tandem mass spectrometry method for determination of free estrogens and their conjugates in river water. Analytica Chimica Acta, 627(1), 91-98.

Qu, S., Kolodziej, E. P., \& Cwiertny, D. M. (2012). Phototransformation rates and mechanisms for synthetic hormone growth promoters used in animal agriculture. Environmental Science \& Technology, 46(24), 13202-13211.

Rice, D. A., McMurray, C. H., \& Davidson, J. F. (1983). Ketosis in dairy cows caused by low levels of lincomycin in concentrate feed. Veterinary Record, 113(21) 495-496.

Robert, C., Gillard, N., Brasseur, P. Y., Ralet, N., Dubois, M., \& Delahaut, P. (2015) Rapid multiresidue and multi-class screening for antibiotics and benzimidazoles in feed by ultra high performance liquid chromatography coupled to tandem mass spectrometry. Food Control, 50, 509-515.

Roe, M. T., \& Pillai, S. D. (2003). Monitoring and identifying antibiotic resistance mechanisms in bacteria. Poultry Science, 82(4), 622-626.

Sapkota, A., Sapkota, A. R., Kucharski, M., Burke, J., McKenzie, S., Walker, P., et al. (2008). Aquaculture practices and potential human health risks: current knowledge and future priorities. Environment International, 34, 1215-1226.

Schrager, S., \& Potter, B. E. (2004). Diethylstilbestrol exposure. American Family Physician, 69, 2395-2400.

Sczesny, S., Nau, H., \& Hamscher, G. (2003). Residue analysis of tetracyclines and their metabolites in eggs and in the environment by HPLC coupled with microbiological assay and tandem mass spectrometry. Journal of Agricultural and Food Chemistry, 51, 697-703.

Secundo, F., Bacigalupo, M. A., Scalera, C., \& Quici, S. (2012). Rapid time-resolved fluoroimmunoassay for diethylstilbestrol in cow milk samples with a highly luminescent Tb3+ chelate. Journal of Food Composition and Analysis, 25, $221-225$.

Shao, B. Jia, X, Zhang, J., Meng, J., Wu, Y., Duan, H., et al. (2009). Multi-residua analysis of $16 \beta$-agonists in pig liver, kidney and muscle by ultra performance liquid chromatography tandem mass spectrometry. Food Chemistry, 114(3) $1115-1121$

Shore, L. S., Shemesh, M., \& Cohen, R. (1988). The role of oestradiol and oestrone in chicken manure silage in hyperoestrogenism in cattle. Australian Veterinary Journal, 65(2), 68-68.

Smith, M. (2014). Veterinary drugs residues: anabolics. In Y. Motarjemi (Ed.)
Encyclopedia of food safety (Vol. 3, pp. 55-62). Waltham, MA: Academic

Stokstad, E. R. R., Jukes, T. H., Pierce, F., Page, A. C., \& Franklin, A. L. (1949). The multiple nature of A.P.F. Journal of Biological Chemistry, 180, 647.

Stolker, A. A. M., Zuidema, T., \& Nielen, M. W. F. (2007). Residue analysis of veterinary drugs and growth-promoting agents. Trends in Analytical Chemistry, 26(10), 968-979.

Thiele-Bruhn, S. (2003). Pharmaceutical antibiotic compounds in soils-a review. Journal of Plant Nutrition and Soil Science, 166, 145-167.

Van Boeckel, T. P., Brower, C., Gilbert, M., Grenfell, B. T., Levin, S. A., Robinsoni, T. P., et al. (2015). Global trends in antimicrobial use in food animals. Proceedings of the National Academy of Sciences, 112(18), 5649-5654.

Van den Belt, K., Wester, P. W., van der Ven, L., Verheyen, R., \& Witters, H. (2002). Effects of ethynylestradiol on the reproductive physiology in zebrafish (Danio rerio): time dependency and reversibility. Environmental Toxicology and Chemistry, 21(4), 767-775.

Van den Bogaard, A. E., London, N., Driessen, C., \& Stobberingh, E. E. (2001). Antibiotic resistance of faecal Escherichia coli in poultry, poultry farmers and poultry slaughterers. Journal of Antimicrobial Chemotherapy, 47(6), 763-771.

Vanhaecke, L., Vanden Bussche, L., Wille, K., Bekaert, K., \& De Brabander, H. F. (2011). Ultra-high performance liquid chromatography-tandem mass spectrometry in high-throughput confirmation and quantification of 34 anabolic steroids in bovine muscle. Analytica Chimica Acta, 700, 70-77.

Vasconcelos, J. T., Rathmann, R. J., Reuter, R. R., Leibovich, J., McMeniman, J. P., Hales, K. E., et al. (2008). Effects of duration of zilpaterol hydrochloride feeding and days on the finishing diet on feedlot cattle performance and carcass traits. Journal of Animal Science, 86(8), 2005-2015.

Vieira, E. S., \& Gomes, J. A. N. F. (2009). A comparison of scopus and Web of Science for a typical university. Scientometrics, 81(2), 587-600.

Wang, P., Wang, X., Zhang, W., \& Su, X. (2014). Development of "one-pot" method for multi-class compounds in porcine formula feed by multi-function impurity adsorption cleaning followed ultra-performance liquid chromatographytandem mass spectrometry detection. Journal of Chromatography B: Analytical Technologies in the Biomedical and Life Sciences, 947-948, 192-200.

Wang, H., Zhang, Y., Li, H., Du, B., Ma, H. M., Wu, D., et al. (2013). A silver-palladium alloy nanoparticle-based electrochemical biosensor for simultaneous detection of ractopamine, clenbuterol and salbutamol. Biosensors and Bioelectronics, 49, 14-19.

WHO \& FAO. (2015). Codex alimentarius: Codex texts on foodborne antimicrobial resistance (p. 223). Food an Agriculture Organization of the United Nations and World Health Organization.

Wierup, M. (2001). The Swedish experience of the 1986 year ban of antimicrobial growth promoters, with special reference to animal health, disease prevention, productivity, and usage of antimicrobials. Microbial Drug Resistance, 7(2), 183-190.

Wu, C., Spongberg, A. L., Witter, J. D., Fang, M., \& Czajkowski, K. P. (2010). Uptake of pharmaceutical and personal care products by soybean plants from soils applied with biosolids and irrigated with contaminated water. Environmental Science and Technology, 44, 6157-6161.

Xu, J., Li, Y., Guo, J., Shen, F., Luo, Y., \& Sun, C. (2014). Fluorescent detection of clenbuterol using fluorophore functionalized gold nanoparticles based on fluorescence resonance energy transfer. Food Control, 46, 67-74.

Yang, S., Liu, X., Xing, Y. Y., Zhang, D. P., Wang, S., Wang, X. B., et al. (2013). Detection of clenbuterol at trace levels in doping analysis using different gas chromatographic-mass spectrometric techniques. Journal of Chromatographic Science, 51, 436-445.

Zhang, G. J., Fang, B. H., Liu, Y. H., Wang, X. F., Xu, L. X., Zhang, Y. P., et al. (2013). Development of a multi-residue method for fast screening and confirmation of 20 prohibited veterinary drugs in feedstuffs by liquid chromatography tandem mass spectrometry. Journal of Chromatography B: Analytical Technologies in the Biomedical and Life Sciences, 936, 10-17.

Zhang, X. F., Zhao, H., Xue, Y., Wu, Z. J., Zhang, Y., He, Y. J., et al. (2012). Colorimetric sensing of clenbuterol using gold nanoparticles in the presence of melamine. Biosensors and Bioelectronics, 34, 112-117.

Zhou, J., Li, Y., Liu, Q., Fu, G., \& Zhang, Z. (2013). Capillary electrophoresis of clenbuterol enantiomers and NMR investigation of the clenbuterol/carboxymethyl$\beta$-cyclodextrin complex. Journal of Chromatographic Science, 51(3), 237-241.

Zuccato, E., Castiglioni, S., Bagnati, R., Melis, M., \& Fanelli, R. (2010). Source, occurrence and fate of antibiotics in the Italian aquatic environment. Journal of Hazardous Materials, 179, 1042-1048. 